\title{
Antibacterial Activity of Ethyl Acetate Extract of Endophytic Fungus (Paraconiothyrium Brasiliense) Through Targeting Pathogenesis Related Dihydropteroate Synthase (DHPS)
}

Anbazhagan Sathiyaseelan

Kangwon National University

Kandasamy Saravanakumar

Kangwon National University

Mariadoss Arokia Vijay Anand

Kangwon National University

M Wang (D mhwang@kangwon.ac.kr)

Kangwon National University

\section{Research Article}

Keywords: Paraconiothyrium brasiliense, GC-MS, Antioxidant, Cytotoxicity, Antibacterial, DHPS

Posted Date: July 16th, 2021

DOl: https://doi.org/10.21203/rs.3.rs-691210/v1

License: (c) (i) This work is licensed under a Creative Commons Attribution 4.0 International License.

Read Full License 


\section{Abstract}

Endophytic fungi are innumerable sources of bioactive metabolites with various biomedical applications. Hence, this study was aimed to isolate and identify the endophytic fungus Paraconiothyrium brasiliense (PB) from the fruit of Capsicum annuum and evaluated their biochemical, antimicrobial, antioxidant, cell viability, and cytotoxicity behavior. Results showed that ethyl acetate extract (EAE) of PE contains flavonoid (31.53 $\pm 0.9 \mathrm{mg}$ of QE/g of extract) and phenolic ( $2.59 \pm 0.06 \mathrm{mg}$ of GAE/g of extract). The PBEAE showed significant antioxidant activity in terms of free radicals such as DPPH, ABTS, and $\mathrm{Fe}^{3+}$ scavenging. The antioxidant potential of PB-EAE reflects in normal cell viability and anticancer activity against prostate cancer (PC3) cells. The bacterial inhibitory activity of PB-EAE was equal to commercial antibiotic tetracycline hydrochloride (TCH). Further, GC-MS analysis confirmed the presence of volatile molecules such as o-cymene $\left(\mathrm{CH}_{3} \mathrm{C}_{6} \mathrm{H}_{4} \mathrm{CH}\left(\mathrm{CH}_{3}\right)_{2}\right)$, dipentene $\left(\mathrm{C}_{10} \mathrm{H}_{16}\right)$, $\mathrm{Y}$-terpinene $\left(\mathrm{C}_{10} \mathrm{H}_{16}\right)$, 4carvomenthenol $\left(\mathrm{C}_{10} \mathrm{H}_{18} \mathrm{O}\right)$, heneicosane $\left(\mathrm{CH}_{3}\left(\mathrm{CH}_{2}\right)_{19} \mathrm{CH}_{3}\right)$, 2,5-piperazinedione $\left(\mathrm{C}_{4} \mathrm{H}_{6} \mathrm{~N}_{2} \mathrm{O}_{2}\right)$. Also, molecular docking analysis demonstrated the significant interactions between the compounds of PB-EAE and Dihydropteroate Synthase (Protein ID:5JQ9; DHPS). This study revealed that endophytic $P$. brasiliense from Capsicum annuum could be a novel source for the isolation of antimicrobials.

\section{Introduction}

Emerging microbial infections, diseases, and antimicrobial resistance (AMR) by bacteria, fungi, and parasites are believed to the potential risks to living beings [1]. Hence, there is the need to discover and develop efficient drugs against microbial infection-associated diseases. At the same time, plant endophytic fungi are widely reported as the sources of novel secondary metabolites such as terpenes, terpenoids, polyketides, alkaloids, and flavonoids [2, 3]. Those obtainable secondary metabolites from endophytes have significant biological properties such as antibacterial, antifungal, antiviral, antioxidant, anti-inflammatory, anticancer, antidiabetic, insecticidal, and immunomodulatory [4]. Endophytic fungi are symbiotic microorganisms that are colonized in the living tissues of the plants and other living materials and assists to defends the various biological, environmental factors [5, 6]. Also, endophytic fungi colonization in plants plays a key role in determining secondary metabolites production [7]. Endophytic fungi were often isolated from various sources (terrestrial and aquatic plants, marine organisms (algae, seagrasses, vertebrates, and invertebrates) [8-11]. The group of bioactive secondary metabolites and their biological activities differed according to the sources of isolation $[12,13]$.

The bioactive molecules such as paclitaxel, resveratrol, camptothecin, huperzine A, and podophyllotoxin are known to isolate from endophytic fungi Penicillium sp., Aspergillus sp., Alternaria sp., Trichoderma sp., Fusarium sp., and Phomopsis sp., [14]. Among the endophytic fungi, $P$. brasiliense strains are explored from different plant sources such as Chinese maple leaves [15], Chloranthus japonicus [16]. The isolation of novel Paraconiothyrium sp., such as $P$. africanum, and $P$. brasiliense reported from Prunus persica, $P$. hawaiiense from Sophora chrysophylla, and $P$. variabile from Actinidia chinensis [17]. A study reported that bisbolane sesquiterpenoids isolated from endophytic fungus $P$. brasiliense (M3-3341) associated with the Acer truncatum [18]. Further, bisbolane sesquiterpenoids (brailamide E (1)) and 
derivative compounds showed significant anticancer activity when testing with the MCF-7 cell line [18, 19]. A study reports that brasilamide K-N (1-4) and new bergamotane sesquiterpenoids were isolated from the $P$. brasiliense through the fermentation process[20]. Interestingly, paraconfuranones A-H and I-M were reported from Acrida cinerea gut-associated $P$. brasiliense [21, 22]. A new ketol compound (sporulosol) was isolated from $P$. sporulosum and found that showed significant anticancer activity against different cancer cell lines [23]. The recent study reports that ten new sesquiterpenoids such as paraconiothins A-J were isolated from P. brasiliense ECN258 associated with Cinnamomum camphora [24]. Dihydropteroate synthase (DHPS) is a key enzyme involved in dihydrofolate synthesis in microorganisms and plants. Further, dihydrofolate is required to make the nitrogenous base (purines and pyrimidines) of DNA and RNA. Hence the inhibition of the DHPS enzyme is an important target for achieving antimicrobial activities [25].

Therefore, endophytic fungi could be the key source for the drug discovery and development of several diseases. However, among the large group of endophytic fungi, a limited number of fungal secondary metabolites were reported. Further, isolated novel compounds and their derivatives are not sufficiently studied for their biological functions. To the overview of the Paraconiothyrium sp., were reported several new terpenoid derivatives but those compounds are just tested their cytotoxicity and not studied their other biological functions such as antioxidant, antibacterial, antidiabetic, etc. Hence, this study aimed to evaluate biochemical and biological activities of ethyl acetate extract of endophytic fungus $P$. brasiliense from Capsicum annum. The biochemical studies include the analysis of total phenol and flavonoid content and volatile compounds analysis by gas chromatography-mass spectrum (GC-MS) analysis. The biological studies include antioxidant, antibacterial, cytotoxic activities. Also, volatile molecules interaction was tested with DHPS enzyme through molecular docking analysis.s

\section{Materials And Methods}

\section{Sample collection and Isolation of endophytic fungus}

The healthy bell pepper (Capsicum annum L.) was purchased from the local former market in Chuncheon, Republic of Korea in May 2020. Then the bell pepper samples were brought to the laboratory and impurities were removed by washing with tap water and distilled water. For the surface sterilization, the bell pepper samples were cut as pieces (approximately $5 \times 5 \mathrm{~mm}$ ) washed with ethanol (95\%), sodium hypochlorite ( $4 \%$ chlorine), and ethanol (95\%) for $1 \mathrm{~min}, 4 \mathrm{~min}$, and $30 \mathrm{~s}$, respectively. Followed by the bacterial cell suspension was prepared by putting the 5 pieces of bell pepper in $10 \mathrm{~mL}$ of $0.9 \%$ sterile saline solution and vortexed for $2 \mathrm{~min}$. Then, $50 \mu \mathrm{L}$ of ten-fold diluted cell suspension was inoculated on potato dextrose agar (PDA) supplemented with tetracycline hydrochloride $(20 \mu \mathrm{g} / \mathrm{mL})$ and incubated at $26 \pm 2^{\circ} \mathrm{C}$ for $72 \mathrm{~h}$. Afterward, about 10 unique single fungal colonies were subculture on PDA plates. Finally, the unique fungal strain (KNUFCPF01) was selected for further molecular identification based on morphological characteristics and antibacterial activities.

\section{Molecular identification}


Fungal strain (KNUFCPF01) was cultured on PDA plates for 3-5 days. Approximately, $100 \mathrm{mg}$ of fungal mycelia were collected without agar and used for gDNA extraction according to the CTAB method reported elsewhere. The isolated fungal gDNA was used as a template to amplify the marker gene internal transcribed spacer (ITS) using the primers ITS1 and ITS2 [26]. The PCR product separated using the $1 \%$ agarose gel electrophoresis and the fragment were isolated and sequenced at macrogen (https://www.macrogen.com/ko/main/index.php). Afterward, the ITS gene sequences data were compared with available ITS data in the NCBI database (https://www.ncbi.nlm.nih.gov/) through Nucleotide BLAST search. The phylogenetic tree was formed to demonstrate the similarity between the existing ITS gene sequence of the same strain along with the out-group of Rhizopus oryzae were obtained from the NCBI GenBank database by the neighbor-joining method using MEGA X software.

\section{Extraction of metabolites}

The fungal strain KNUFCPF01 was cultured in the potato dextrose broth (PDB) at $26 \pm 2^{\circ} \mathrm{C}$ under static conditions for 14 days. Afterward, the culture was filtered using Whatman No 1 filter paper. The obtained culture filtrate was mixed with ethyl acetate 5:1 ratio and collected the upper organic layer. Further, the extraction process was repeated 3-4 times and all the extracts pooled together and condensed using a rotary evaporator at $45^{\circ} \mathrm{C}$. Finally, the ethyl acetate extract (EAE) was collected and stored at room temperature.

\section{Total phenol and flavonoid content}

The total phenol and flavonoid content in PB-EAE were evaluated according to earlier reports [27]. In brief, total phenol content was determined by mixing Folin-phenol reagent $(200 \mu \mathrm{L}), 100 \mu \mathrm{L} E A E(1 \mathrm{mg} / \mathrm{mL})$, and saturated sodium bicarbonate $(200 \mu \mathrm{L})$. After $10 \mathrm{~min}$ incubation at room temperature, $100 \mu \mathrm{L}$ of aliquots were read at $760 \mathrm{~nm}$ using a UV-visible spectrophotometer. For the total flavonoid content determination, $100 \mu \mathrm{L}$ of EAE mixed with ethanol $(150 \mu \mathrm{L})$, distilled water $(280 \mu \mathrm{L}), 10 \%$ of aluminum chloride $(10 \mu \mathrm{L})$, and $1 \mathrm{M}$ potassium acetate $(10 \mu \mathrm{L})$. Further, $100 \mu \mathrm{L}$ of reaction mixture read at $415 \mathrm{~nm}$ using a spectrophotometer. The total phenol and flavonoid content were calculated as gallic acid (GAE) and quercetin (QE) equivalent, respectively.

\section{GC-MS analysis}

The existence of volatile compounds in PB-EAE was determined using Gas chromatograph/mass selective detector (GC/MSD, Agilent Technologies, USA, 7890A, 5975C) analysis. About $10 \mathrm{mg}$ of EAE was dissolved in $10 \mathrm{~mL}$ of methanol. Then $2 \mu \mathrm{L}$ of sample loaded into the Agilent column (DB- $5 \mathrm{~ms}(30 \times 0.25$ $\mathrm{mm}, 0.25 \mu \mathrm{m})$, column flow at $1 \mathrm{~mL} / \mathrm{min}$ with helium gas $(\mathrm{He})$, and interface temperature at $280^{\circ} \mathrm{C}$. The volatile compound was detected by the mass selective detector with the scan range of $40-400 \mathrm{~m} / \mathrm{z}$ and matched with the electronic library (W8N05ST.L).

\section{Antioxidant and enzyme inhibition assay}


Free radical scavenging ability of different concentrations of PB-EAE was determined through DPPH, Ferric reducing and ABTS radical scavenging assay according to the earlier reports [27]. The enzyme (aamylase and a-glucosidase) inhibitory activities of EAE were determined according to the earlier report [28].

\section{Cell culture assay}

The human embryonic kidney cell line (HEK-293 cells), and prostate cancer cell line (PC3 cells) were obtained from the Korea cell line bank. The cells were cultured in a T-25 culture flask using the high glucose DMEM for HEK-293 cells and RPMI media for PC3 cells supplemented with antibiotic penicillin and streptomycin, respectively. Both cells were maintained in a $5 \% \mathrm{CO}_{2}$ incubator at $37^{\circ} \mathrm{C}$. Cell viability of PB-EAE was determined using a WST viability assay kit. Both cells $\left(1 \times 10^{4}\right)$ were seeded into the 96 -well plate individually containing the respective cell culture media and incubated for $24 \mathrm{~h}$. Subsequently, $10 \mu \mathrm{L} /$ well of different concentrations of PB-EAE were treated and incubated for $12 \mathrm{~h}$. Then, WST reagent $(10 \mu \mathrm{L} /$ well) was added and continued the incubation for $1 \mathrm{~h}$. Afterward, the 96 -well culture plate was read at $450 \mathrm{~nm}$. The cell viability (\%) was determined according to the earlier report [29]. Further, the $\mathrm{IC}_{50}$ of the EAE for PC3 cells was evaluated using different apoptotic fluorescent staining assays according to the earlier report [30].

\section{Antibacterial activity}

The bacterial inhibition ability of PB-EAE was evaluated by well diffusion assay in both Gram-positive (Bacillus cereus (ATCC 14579), Staphylococcus aureus (ATCC 19095), and Listeria monocytogens (ATCC 19115)) and Gram-negative (Escherichia coli (ATCC 43888) and Salmonella enterica (ATCC 14028) bacterial pathogens. The bacterial pathogens were obtained from the American Type Culture Collection (ATCC), University Blvd, Manassas, US. For the antibacterial assay, each bacterial strain was cultured in nutrient broth at the density of $1 \times 10^{9}$ (colony-forming units $(\mathrm{CFU}) / \mathrm{mL}$ ) and it was swapped onto a Muller-Hinton agar (MHA) plate using a cotton swab. Then, wells were made by metal cork-borer, the different concentrations of EAE were added to each well along with the positive control (tetracycline hydrochloride). Afterward, these plates were incubated at $37^{\circ} \mathrm{C}$ overnight. After incubation, the antibacterial activity was determined in terms of the zone of inhibition. The minimum inhibitory concentration of EAE determined by the broth dilution method was reported elsewhere [31]. In brief, different concentration of $10 \mu \mathrm{L}$ of EAE of endophytic fungus (1000, 500, 250, 125, 62.5, 31.25, 15.62, 7.8, $3.9 \mu \mathrm{g} / \mathrm{mL})$ was treated with each bacterial culture $\left(5 \times 10^{5} \mathrm{CFU} / \mathrm{mL}\right)$ in $100 \mu \mathrm{L}$ of MHB medium in 96 well plate for $24 \mathrm{~h}$. After incubation, the plates have measured the absorbance at $600 \mathrm{~nm}$ for calculation of MIC.

\section{In vivo molecular docking analysis}


Further, the antibacterial molecular mechanism of volatile molecules in the PB-EAE was demonstrated by molecular docking analysis with Yersinia Pestisis dihydropteroate Synthase (DHPS) enzyme (5JQ9). Firstly, the volatile molecules of EAE were tested and selected depends on their drug-likeness giving to Lipinski's rules [32]. The volatile molecule structure was developed using colonial smiles from $\mathrm{NIH}$ PubChem (https://pubchem.ncbi.nlm.nih.gov/) and energy minimalized by UCSF chimera 1.14. Besides, the target bacterial DHPS enzyme (PDB ID: 5JQ9) was obtained from the RCSB protein data bank (https://www.rcsb.org/). The molecular docking analysis was done in Argus Lab (Version 4.0.1), and then the results of interactions were visualized using BIOVIA Discovery Studio Visualizer (v20.1.0.19295).

\section{Statistical analysis}

All the experiments were done individually at least thrice, and results were shown as the means with standard deviation (SD). The statistical significance was determined using one-way analysis variance (ANOVA). $p<0.05$, statistically considered as the significance.

\section{Results And Discussion}

\section{Isolation and molecular identification of strain KNUFCPF01}

Among the different fungal isolates, the endophytic fungal strain KNUFCPF01 (Fig. 1A) was selected and identified by sequencing of the ITS region (ITS1, 5.8S, and ITS2 of gDNA. The gene sequencing of strain KNUFCPF01 was identified as $P$. brasiliense (MT269522). A study reported that endophytic fungus Paraconiothyrium sp. was isolated from the root of Capsicum annum [33]. Those finding was supported the existence of Paraconiothyrium sp. in Capsicum annum. Further, the phylogenetic relationship among the $P$. brasiliense strains and other genera was studied and shown in Fig. 1B. The neighbor-joining method of MT269522, a phylogenetic tree constructed using gene sequences of partial ITS1 and ITS2, complete 5.8S rRNA in MEGA X. The phylogenetic tree showed that strain MT269522 was clustered the similarity with Paraconiothyrium strains whereas $R$. oryzae was used as an outgroup.

\section{Biochemical analysis}

The TPC and TFC of PB-EAE showed $2.59 \pm 0.06 \mathrm{mg} / \mathrm{g}$ of gallic acid equivalent and $31.53 \pm 0.90 \mathrm{mg} / \mathrm{g}$ of quercetin equivalent (Table 1). The results indicated that the TPC of PB-EAE was lower than TFC. Similarly, EA extract of endophytic fungal strain Fritillaria unibracteata var. exhibits the different concentrations of phenolic, flavonoid saponin that responsible for the biological properties [34]. The phenolics, flavonoids, and terpenoids are widely reported as antioxidant, antibacterial, and anticancer compounds [34-36]. Further, the volatile compound profile of PB-EAE was determined by GC-MS analysis (Fig. 2). Table 2 shows the retention time, peak area, compound name, molecular formula, and molecular weight of the volatile compound from EAE of $P$. brasiliense. The results predicted that existence of 12 major bioactive volatile compounds such as 2,3-butylene glycol $\left(\mathrm{CH}_{3} \mathrm{CH}(\mathrm{OH}) \mathrm{CH}(\mathrm{OH}) \mathrm{CH}_{3}\right)$, isopentyl acetate $\left(\mathrm{CH}_{3} \mathrm{COOCH}_{2} \mathrm{CH}_{2} \mathrm{CH}\left(\mathrm{CH}_{3}\right)_{2}\right)$, o-cymene $\left(\mathrm{CH}_{3} \mathrm{C}_{6} \mathrm{H}_{4} \mathrm{CH}\left(\mathrm{CH}_{3}\right)_{2}\right)$, dipentene $\left(\mathrm{C}_{10} \mathrm{H}_{16}\right)$, y-terpinene 
$\left(\mathrm{C}_{10} \mathrm{H}_{16}\right)$, 3,5-nonadien-7-yn-2-ol $\left(\mathrm{C}_{9} \mathrm{H}_{12} \mathrm{O}\right)$, 2-phenylethanol $\left(\mathrm{C}_{6} \mathrm{H}_{5} \mathrm{CH}_{2} \mathrm{CH}_{2} \mathrm{OH}\right)$, 4-carvomenthenol $\left(\mathrm{C}_{10} \mathrm{H}_{18} \mathrm{O}\right)$, 2-phenethyl acetate $\left(\mathrm{CH}_{3} \mathrm{COOCH}_{2} \mathrm{CH}_{2} \mathrm{C}_{6} \mathrm{H}_{5}\right)$, heneicosane $\left(\mathrm{CH}_{3}\left(\mathrm{CH}_{2}\right)_{19} \mathrm{CH}_{3}\right)$, 2,4-di-tertbutylphenol $\left(\left[\left(\mathrm{CH}_{3}\right)_{3} \mathrm{C}_{2} \mathrm{C}_{6} \mathrm{H}_{3} \mathrm{OH}\right)\right.$, and 2,5-piperazinedione $\left(\mathrm{C}_{4} \mathrm{H}_{6} \mathrm{~N}_{2} \mathrm{O}_{2}\right)$. The 2,3-butylene glycol was reported a substantial presence in the seeds of Dimocarpus longan Lour. which is used for wine production and facilitates antioxidant properties [37]. 2, 3-butylene glycol helpful for plant-microbe interactions and act as an elicitor [38]. Also, the derivative of 1, 3-butylene glycol exhibited potent antibacterial and antifungal activities [39]. Similarly, the compound isopentyl acetate from endophytic Bacillus subtilis inhibits the growth and sporulation of Curvularia lunata [40]. Cymene isomers are reported to possess insecticidal and repellent properties [41]. Also, the recent studies confirmed that ocymene has an inhibitory effect against the H1N1 influenza virus [42] and coronavirus 2 [43]. The study assumes that the maximum existence same molecular weight derivative of dipentene, and $y$-terpinene in black pepper was the reason for antioxidant activity [44]. The 4-carvomenthenol is a fragrance molecule [45] and it has the property to recover from allergic rhinitis and asthma syndrome [46]. 2,5-

Piperazinedione derivatives from Penicillium griseofulvum exhibited immunosuppressive activity in antiCD3/anti-CS28 stimulated murine splenocytes [47]. Also, diketopoperazines derivatives were isolated from endophytic fungus Bionectria sp. Y1085 showed significant antibacterial activity[48]. Further, ascotoxin reported from EA extract of Capsicum annum root endophytic fungus Paraconiothyrium sp. inhibit the seed germination of wild grass (Echinochloa crus-galli) [33]. Also, the study reported that 1,8dihydroxyanthraquinone from endophytic Paraconiothyrium sp. from Zingiber officinale Rosc. and it was shown in broad spectrum of antimicrobial activity against human pathogenic bacteria and phytopathogenic fungi [49].

\section{Antioxidant activity}

Antioxidant molecules are functioning as the substrate to quenching the incomplete oxygen reduction of reactive oxygen species (ROS) formation in mitochondria thereby protects the cells from oxidative damage $[50,51]$. Also, the increased level of ROS oncogenic signaling molecules initiates uncontrolled cell proliferation [51]. To reduce chronic and degenerative diseases, antioxidant molecules have been used widely from different sources (bacteria, algae, fungi, and plants) $[52,53]$. The present study showed that EAE of $P$. brasiliense contains a wide range of antioxidant molecules which are identified from biochemicals content and volatile compounds profile analysis. Hence, EAE of $P$. brasiliense was tested for inhibition of ROS formation by DPPH and ABTS radical scavenging assay and ferric reducing power assay (Table 1). According to the experimental result, the EAE of $P$. brasiliense showed the IC50 concentration for DPPH radical scavenging at $383.51 \pm 6.97 \mu \mathrm{g} / \mathrm{mL}$ compared to ascorbic acid at $69.11 \pm$ $0.99 \mu \mathrm{g} / \mathrm{mL}$. Similarly, a previous study reported that EA extract of Paraconiothyrium sp. P83F4/1 showed potential DPPH activity [54]. Also, the EA extract of $P$. brasiliense showed the IC50 concentration for ABTS radical scavenging at $29.57 \pm 1.56 \mu \mathrm{g} / \mathrm{mL}$ compared to ascorbic acid $41.84 \pm 1.37 \mu \mathrm{g} / \mathrm{mL}$. The same way EA extract of endophytic fungus Diaporther $s p$. showed ABTS radical scavenging activity [55]. In addition, EA extract of $P$. brasiliense showed the IC50 concentration for ferric reducing power at $358 \pm$ 
$10.33 \mu \mathrm{g} / \mathrm{mL}$ compared to ascorbic acid $317.6 \pm 4.11 \mu \mathrm{g} / \mathrm{mL}$. Similarly, endophytic fungal (Fritillaria unibracteata var.) extract reported that required a higher concentration for reduction of ferric ion to ferrous [34]. Based on the different antioxidant assays, we concluded that EA extract of $P$. brasiliense could be the potential source for the isolation of antioxidant molecules.

\section{Cell viability}

Cell viability assay is used to determine how the metabolites or drug molecules affect cell proliferation and its biochemical changes. In order to test the cell viability effect, EAE of $P$. brasiliense, HEK-293 cells, and PC3 cells were used, and cell viability was determined by the WST assay method [56]. The EAE of $P$. brasiliense treated PC3 cells were showed the IC50 concentration at $187.3 \pm 9.29 \mu \mathrm{g} / \mathrm{mL}$ while HEK293 cells did not show any IC50 concentration up to a tested concentration of $1000 \mu \mathrm{g} / \mathrm{mL}$ (Fig. 3). Similarly, EA extract of endophytic Phomopsis sp. did not affect the normal cell (HeLa cells) proliferation while showed the anticancer activity against breast cancer cell line (MCF-7) [57]. Hence, the results revealed that EAE of $P$. brasiliense showed toxicity against cancer cells but not in a normal cell. Further, EAE of $P$. brasiliense treated PC3 cell viability and apoptotic changes evaluated using different fluorescent staining. The results of nuclear staining (PI and DAPI) demonstrated that more dead cells population in EAE of $P$. brasiliense treatment compared to untreated control PC3 cells (Fig. 4). The mitochondrial membrane potential of cells was determined using a rhodamine 123 fluorescent stain. The results indicated that EAE of $P$. brasiliense treated cells were lost the mitochondrial membrane potential compared to control. Also, the higher ROS elevation was observed in EAE of $P$. brasiliense treated cells but not observed in control cells evaluated by DCFH-DA staining. The overall results revealed that EAE of $P$. brasiliense had the excellent cytotoxic behavior on PC3 cells but less toxic to normal cells. Similarly, the study reported that brasilamide E (1) from P. brasiliense showed the toxicity to cancer cells (H08910, MCF-7, and HeLa) while non-toxic to normal cell (NIH3T3)[19]. Also, ketal compound sporulosol exhibited considerable cytotoxicity to HeLa, T24, A549, HCT116, and SH-SY5Y cells [23]. But isolated eight furanone compounds (paraconfuranones A-H) from P. brasiliense MZ-1 did not show any toxicity to A549, HepG2, and CaSki cells [22].

\section{Antidiabetic assays}

The digestive enzymes play a major role in converting complex sugar molecules into simple sugar molecules through enzymatic digestion [58]. Even if in the case of diabetic patients, blood sugar might be increased than normal people due to the enzymatic action. Hence, the inhibition of enzyme function subsequently decreased the blood sugar level. In the present study, P. brasiliense EA extract did not show considerable digestive enzyme inhibitory activity against a-amylase and a-glucosidase (Data not shown).

\section{Antibacterial activity}


Antibacterial agents are used to killing the bacteria (bactericidal) or slow down the bacterial growth (bacteriostatic). Most of the antibacterial agents were initially isolated from natural sources and then they have been synthesized their own or derivative form for the applications $[59,60]$. However, prolonged use of drugs creates antibiotic-resistant bacterial strains which urge the discovery of novel antibiotics. Hence, EAE of $P$. brasiliense was evaluated for its antibacterial efficacy with bacterial pathogens such as B. cereus, S. aureus, L. monocytogenes, E. coli, and S. enterica (Fig. 5). The results showed that EAE of $P$. brasiliense had substantial inhibitory activity against both Gram-positive and Gram-negative bacteria. The inhibitory activity depending on the concentration that means when increasing/decreasing the EA extract concentration, the bacterial inhibition activity was increased/decreased, respectively. Among the different concentrations of EAE of $P$. brasiliense, $50 \mu \mathrm{L}$ of maximum tested concentration $(1000 \mu \mathrm{g} / \mathrm{mL})$ showed the zone of inhibition at $17 \pm 1.2 \mathrm{~mm}$ for $B$. cereus, $22 \pm 1.4 \mathrm{~mm}$ for $S$. aureus, $24 \pm 1.4 \mathrm{~mm}$ for $L$. monocytogens, $8 \pm 0.4 \mathrm{~mm}$ for E. coli, and $21 \pm 1.6 \mathrm{~mm}$ for $S$. enterica (Table 3). Also, the positive control $20 \mu \mathrm{L} \mathrm{TCH}(1000 \mu \mathrm{g} / \mathrm{mL})$ exhibited the zone of inhibition $21 \pm 1.2 \mathrm{~mm}$ for $B$. cereus, $22 \pm 1.2 \mathrm{~mm}$ for $S$. aureus, $23 \pm 1.4 \mathrm{~mm}$ for $L$. monocytogens, $12 \pm 1.2 \mathrm{~mm}$ for $E$. coli, and $21 \pm 1.4 \mathrm{~mm}$ for $S$. enterica. Interestingly, the EAE of $P$. brasiliense showed significant antibacterial activity $(p<0.05)$, which is the same as the antibiotic TCH. The minimum inhibitory concentration of EAE of $P$. brasiliense showed $B$. cereus at $31.25 \mu \mathrm{g} / \mathrm{mL}$, for $S$. aureus at $15.62 \mu \mathrm{g} / \mathrm{mL}$, L. monocytogens at $15.62 \mu \mathrm{g} / \mathrm{mL}, E$. coli at 62.5 $\mu \mathrm{g} / \mathrm{mL}$, and S. enterica at $15.62 \mu \mathrm{g} / \mathrm{mL}$. Similarly, endophytic Paraconiothyrium sp. isolated from Zingiber officinale Rosc. showed considerable antibacterial activity against clinical pathogens [49]. But the antibacterial properties of Paraconiothyrium sp. were studied inadequately the research gap could be filled by future studies.

\section{Molecular docking analysis}

Molecular docking analysis was performed to identify the interaction of metabolites with the molecular target of anti-bacterial activity. The inhibition of dihydropteroate synthase (DHPS) is one of the key mechanisms to kill the bacterial or inhibit bacterial growth through pterin-sulfonamide conjugation [61]. According to those strategies, the identified volatile compounds from EA extract of $P$. brasiliense interact with DHPS. The results indicated that out of 12 volatile compounds, 10 compounds completely satisfied Lipinski's rules (Table 4). Further, molecular docking analysis of major volatile compounds was tested with DHPS (5JQ9) was shown in Table 5 and Fig. 6 . The docking results showed that 5 volatile compounds such as o-cymene, dipentene, $\gamma$-terpinene, heneicosane, and 2,4-di-tert-butylphenol had the higher molecular interaction according to the binding energy. But those volatile compounds had no hydrogen bonding, which indicated that antibacterial mechanism might be done other than inhibition of DHPS mechanisms. Interestingly, one of the volatile compounds 2,5-piperazinedione showed less binding energy $(-5.20 \mathrm{kcal} / \mathrm{mol})$ with greater hydrogen bonding (PR015; THR53; VAL17; GLY51) (Fig. 5) comparing to other volatiles tested in the present study.

\section{Conclusion}


In the present study, endophytic fungus (Paraconiothyrium brasiliense MT269522) was isolated from the fruit of Capsicum annum $L$. and reported for the first time. The EAE of $P$. brasiliense (NCBI accession no. MT269522) contains bioactive volatile compounds such as $y$-terpinene, 4-carvomenthenol, heneicosane, 2,5-piperazinedione. Therefore, EAE of $P$. brasiliense significantly inhibits $\mathrm{DPPH}, \mathrm{ABTS}^{+}$, and ferric ion free radical formation. In addition, the EAE did not show any toxicity to HEK293 cells, but notable cytotoxicity to cancer cells (PC3). Interestingly, the EAE of $P$. brasiliense showed broad-spectrum antibacterial activity against human Gram-positive and Gram-negative bacterial pathogens as equal to standard antibiotic tetracycline hydrochloride. Also, molecular docking analysis confirmed 2,5-piperazinedione had the considerable interaction with DHPS enzyme thereby induced antibacterial activity like sulfonamide class of antibiotic. We conclude that EAE of endophytic fungus ( $P$. brasiliense) could be a potential source for the discovery of antioxidant, anticancer, and antimicrobial molecules.

\section{Declarations}

\section{Ethics Approval}

This article does not contain any studies with animals or human participants.

\section{Consent to Participate}

The authors agreed to participate in this work.

\section{Consent for Publication}

The authors agreed to publish this work.

\section{Author Contributions}

A. Sathiyaseelan: Conceptualization, Data curation, Formal analysis, Investigation, Methodology, Visualization, Writing - original draft, Writing - review \& editing. K. Saravanakumar: Validation, Data curation, Writing - review \& editing. A.V.A. Mariadoss: Formal analysis, Data curation, Software. M-H. Wang: Funding acquisition, Project administration, Resources, Supervision, Validation, Writing - review \& editing.

\section{Funding}

This work was supported by the National Research Foundation of Korea (2021R111A1A01057742). 


\section{Conflict of Interest}

The authors declare no competing interests.

\section{Availability of data and materials}

The data generated and analyzed during the current study are available from the corresponding author on reasonable request.

\section{References}

1. Antimicrobial resistance. (n.d.). Retrieved June 21, from https://www.who.int/news-room/factsheets/detail/antimicrobial-resistance

2. Rustamova, N., Bozorov, K., Efferth, T., \& Yili, A. (2020, April 1). Novel secondary metabolites from endophytic fungi: synthesis and biological properties. Phytochemistry Reviews. Springer. https://doi.org/10.1007/s11101-020-09672-x

3. Zhao, L. X., Xu, L. H., \& Jiang, C. L. (2012). Methods for the study of endophytic microorganisms from traditional Chinese medicine plants. Methods in Enzymology (1st ed., Vol. 517). Elsevier Inc. https://doi.org/10.1016/B978-0-12-404634-4.00001-2

4. Ezeobiora, C. E., Igbokwe, N. H., Amin, D. H., \& Mendie, U. E. (2021). Endophytic microbes from Nigerian ethnomedicinal plants: a potential source for bioactive secondary metabolites-a review. Bulletin of the National Research Centre, 45(1), 103. https://doi.org/10.1186/s42269-021-00561-7

5. Nair, D. N., \& Padmavathy, S. (2014). Impact of endophytic microorganisms on plants, environment and humans. The Scientific World Journal. https://doi.org/10.1155/2014/250693

6. Fadiji, A. E., \& Babalola, O. O. (2020, May 15). Elucidating Mechanisms of Endophytes Used in Plant Protection and Other Bioactivities With Multifunctional Prospects. Frontiers in Bioengineering and Biotechnology. Frontiers Media S.A. https://doi.org/10.3389/fbioe.2020.00467

7. Jia, M., Chen, L., Xin, H. L., Zheng, C. J., Rahman, K., Han, T., \& Qin, L. P. (2016). A friendly relationship between endophytic fungi and medicinal plants: A systematic review. Frontiers in Microbiology. Frontiers Research Foundation. https://doi.org/10.3389/fmicb.2016.00906

8. Hamzah, T. N. T., Lee, S. Y., Hidayat, A., Terhem, R., Faridah-Hanum, I., \& Mohamed, R. (2018). Diversity and characterization of endophytic fungi isolated from the tropical mangrove species, Rhizophora mucronata, and identification of potential antagonists against the soil-borne fungus, Fusarium solani. Frontiers in Microbiology, 9(JUL), 1707. https://doi.org/10.3389/fmicb.2018.01707

9. Frontiers in Pharmacology. Frontiers Media S.A. https://doi.org/10.3389/fphar.2018.00309

10. El-Bondkly, E. A. M., El-Bondkly, A. A. M., \& El-Bondkly, A. A. M. (2021). March 1). Marine endophytic fungal metabolites: A whole new world of pharmaceutical therapy exploration. Heliyon. Elsevier Ltd. https://doi.org/10.1016/j.heliyon.2021.e06362 
11. Singh, A., Singh, D. K., Kharwar, R. N., White, J. F., \& Gond, S. K. (2021, January 1). Fungal endophytes as efficient sources of plant-derived bioactive compounds and their prospective applications in natural product drug discovery: Insights, avenues, and challenges. Microorganisms. MDPI AG. https://doi.org/10.3390/microorganisms9010197

12. Ibrahim, S. R. M., Mohamed, S. G. A., Sindi, I. A., \& Mohamed, G. A. (2021, May 1). Biologically active secondary metabolites and biotechnological applications of species of the family Chaetomiaceae (Sordariales): an updated review from 2016 to 2021. Mycological Progress. Springer Science and Business Media Deutschland GmbH. https://doi.org/10.1007/s11557-021-01704-w

13. Ancheeva, E., Daletos, G., \& Proksch, P. (2019). Bioactive Secondary Metabolites from Endophytic Fungi. Current Medicinal Chemistry, 27(11), 1836-1854. https://doi.org/10.2174/0929867326666190916144709

14. Torres-Mendoza, D., Ortega, H. E., \& Cubilla-Rios, L. (2020, June 1). Patents on endophytic fungi related to secondary metabolites and biotransformation applications. Journal of Fungi. MDPI AG. https://doi.org/10.3390/jof6020058

15. Paul, N. C., \& Lee, H. B. (2014). First Record of Endophytic Paraconiothyrium brasiliense Isolated from Chinese Maple Leaves in Korea. The Korean Journal of Mycology, 42(4), 349-352. https://doi.org/10.4489/kjm.2014.42.4.349

16. An, C., Ma, S., Shi, X., Xue, W., Liu, C., \& Ding, H. (2020). Diversity and antimicrobial activity of endophytic fungi isolated from chloranthus japonicus sieb in Qinling Mountains, China. International Journal of Molecular Sciences, 21(17), 1-15. https://doi.org/10.3390/ijms21175958

17. Damm, U., Verkley, G. J. M., Crous, P. W., Fourie, P. H., Haegi, A., \& Riccioni, L. (2008). Novel Paraconiothyrium species on stone fruit trees and other woody hosts. Persoonia: Molecular Phylogeny and Evolution of Fungi, 20, 9-17. https://doi.org/10.3767/003158508X286842

18. Journal of Natural Products, 78(4), 746-753. https://doi.org/10.1021/np5009569

19. Zhang, Y., Zhang, Z., Wang, B., Liu, L., \& Che, Y. (2016). Design and synthesis of natural product derivatives with selective and improved cytotoxicity based on a sesquiterpene scaffold. Bioorganic and Medicinal Chemistry Letters, 26(8), 1885-1888. https://doi.org/10.1016/j.bmcl.2016.03.022

20. Guo, Z., Ren, F., Che, Y., Liu, G., \& Liu, L. (2015). New bergamotane sesquiterpenoids from the plant endophytic fungus paraconiothyrium brasiliense. Molecules, 20(8), 14611-14620. https://doi.org/10.3390/molecules200814611

21. Liu, C. X., Yu, X. Q., Guo, Z. Y., He, H. B., Tu, X., Deng, Z. S., \& Zou, K. (2016). Structural elucidation and NMR spectral assignments of paraconfuranones I-M from the insect-associated fungus Paraconiothyrium brasiliense. Magnetic Resonance in Chemistry, 54(11), 916-921. https://doi.org/10.1002/mrc.4471

22. Liu, C. X., Wang, L., Chen, J. F., Guo, Z. Y., Tu, X., Deng, Z. S., \& Zou, K. (2015). Paraconfuranones A-H, eight new furanone analogs from the insect-associated fungus Paraconiothyrium brasiliense MZ-1. Magnetic Resonance in Chemistry, 53(4), 317-322. https://doi.org/10.1002/mrc.4197 
23. Zhao, C., Fu, P., Zhang, Y., Liu, X., Ren, F., \& Che, Y. (2018). Sporulosol, a New Ketal from the Fungus Paraconiothyrium sporulosum. Molecules, 23(6), https://doi.org/10.3390/molecules23061263

24. Nakashima, K. I., Tomida, J., Hirai, T., Kawamura, Y., \& Inoue, M. (2019). Paraconiothins A-J: Sesquiterpenoids from the Endophytic Fungus Paraconiothyrium brasiliense ECN258. Journal of Natural Products, 82(12), 3347-3356. https://doi.org/10.1021/acs.jnatprod.9b00638

25. Fernández-Villa, D., Aguilar, M. R., \& Rojo, L. (2019, October 2). Folic acid antagonists: Antimicrobial and immunomodulating mechanisms and applications. International Journal of Molecular Sciences. MDPI AG. https://doi.org/10.3390/ijms20204996

26. White, T. J., Bruns, T., Lee, S., \& Taylor, J. (1990). Amplification and Direct Sequencing of Fungal Ribosomal Rna Genes for Phylogenetics. PCR Protocols, (1), 315-322. https://doi.org/10.1016/b978-0-12-372180-8.50042-1

27. Sathiyaseelan, A., Saravanakumar, K., Mariadoss, A. V. A., Ramachandran, C., Hu, X., Oh, D. H., \& Wang, M. H. (2020). Chitosan-tea tree oil nanoemulsion and calcium chloride tailored edible coating increase the shelf life of fresh cut red bell pepper. Progress in Organic Coatings, 106010. https://doi.org/10.1016/j.porgcoat.2020.106010

28. Sathiyaseelan, A., Saravanakumar, K., Mariadoss, A. V. A., \& Wang, M. H. (2020). Biocompatible fungal chitosan encapsulated phytogenic silver nanoparticles enhanced antidiabetic, antioxidant and antibacterial activity. International Journal of Biological Macromolecules, 153, 63-71. https://doi.org/10.1016/j.ijbiomac.2020.02.291

29. Sathiyaseelan, A., Saravanakumar, K., Mariadoss, A. V. A., \& Wang, M. H. (2021). Antimicrobial and Wound Healing Properties of FeO Fabricated Chitosan/PVA Nanocomposite Sponge. Antibiotics, 10(5), 524. https://doi.org/10.3390/antibiotics10050524

30. Sathiyaseelan, A., Saravanakumar, K., Mariadoss, A. V. A., \& Wang, M. H. (2021). pH-controlled nucleolin targeted release of dual drug from chitosan-gold based aptamer functionalized nano drug delivery system for improved glioblastoma treatment. Carbohydrate Polymers, 262, 117907. https://doi.org/10.1016/j.carbpol.2021.117907

31. Wiegand, I., Hilpert, K., \& Hancock, R. E. W. (2008). Agar and broth dilution methods to determine the minimal inhibitory concentration (MIC) of antimicrobial substances. Nature Protocols, 3(2), 163175. https://doi.org/10.1038/nprot.2007.521

32. Lipinski, C. A. (2004, December 1). Lead- and drug-like compounds: The rule-of-five revolution. Drug Discovery Today: Technologies. Elsevier. https://doi.org/10.1016/j.ddtec.2004.11.007

33. Khan, A. L., Hamayun, M., Hussain, J., Kang, S. M., \& Lee, I. J. (2012). The newly isolated endophytic fungus Paraconiothyrium sp. LK1 produces ascotoxin. Molecules, 17(1), 1103-1112. https://doi.org/10.3390/molecules17011103

34. Pan, F., Su, T. J., Cai, S. M., \& Wu, W. (2017). Fungal endophyte-derived Fritillaria unibracteata var. wabuensis: Diversity, antioxidant capacities in vitro and relations to phenolic, flavonoid or saponin compounds. Scientific Reports, 7(1), 1-14. https://doi.org/10.1038/srep42008

35. PeerJ, 2020(4). https://doi.org/10.7717/peerj.8978 
36. Vasundhara, M., Sudhakara Reddy, M., \& Kumar, A. (2019). Secondary metabolites from endophytic fungi and their biological activities. In New and Future Developments in Microbial Biotechnology and Bioengineering: Microbial Secondary Metabolites Biochemistry and Applications (pp. 237-258). Elsevier. https://doi.org/10.1016/B978-0-444-63504-4.00018-9

37. Tandee, K., Kittiwachana, S., \& Mahatheeranont, S. (2021). Antioxidant activities and volatile compounds in longan (Dimocarpus longan Lour.) wine produced by incorporating longan seeds. Food Chemistry, 348, 128921. https://doi.org/10.1016/j.foodchem.2020.128921

38. Raza, W., \& Shen, Q. (2020). Volatile organic compounds mediated plant-microbe interactions in soil. In Molecular Aspects of Plant Beneficial Microbes in Agriculture (pp. 209-219). Elsevier. https://doi.org/10.1016/b978-0-12-818469-1.00018-3

39. Kinnunen, T., \& Koskela, M. (1991). Antibacterial and antifungal properties of propylene glycol, hexylene glycol, and 1,3-butylene glycol in vitro. Acta Dermato-Venereologica, 71(2), 148-150. https://doi.org/10.2340/0001555571148150

40. Xie, S., Liu, J., Gu, S., Chen, X., Jiang, H., \& Ding, T. (2020). Antifungal activity of volatile compounds produced by endophytic Bacillus subtilis DZSY21 against Curvularia lunata. Annals of Microbiology, 70(1), 1-10. https://doi.org/10.1186/s13213-020-01553-0

41. Feng, Y. X., Zhang, X., Wang, Y., Chen, Z. Y., Lu, X. X., Du, Y. S., \& Du, S. S. (2021). The potential contribution of cymene isomers to insecticidal and repellent activities of the essential oil from Alpinia zerumbet. International Biodeterioration and Biodegradation, 157, 105138. https://doi.org/10.1016/j.ibiod.2020.105138

42. Najar, B., Nardi, V., Stincarelli, M. A., Patrissi, S., Pistelli, L., \& Giannecchini, S. (2021). Screening of the essential oil effects on human H1N1 influenza virus infection: an in vitro study in MDCK cells. Natural Product Research, 1-4. https://doi.org/10.1080/14786419.2021.1944137

43. Journal of Infection and Public Health, 14(5), 601-610. https://doi.org/10.1016/j.jiph.2020.12.037

44. Lee, J. G., Chae, Y., Shin, Y., \& Kim, Y. J. (2020). Chemical composition and antioxidant capacity of black pepper pericarp. Applied Biological Chemistry, 63(1), 35. https://doi.org/10.1186/s13765-02000521-1

45. Bhatia, S. P., McGinty, D., Letizia, C. S., \& Api, A. M. (2008). Fragrance material review on 4carvomenthenol. Food and Chemical Toxicology, 46(11 SUPPL.), S91-S94. https://doi.org/10.1016/j.fct.2008.06.029

46. Bezerra Barros, G. C., Ferreira, P., Ferreira, L. K. D., Monteiro, L. A. M. P. M., Alves, T., de Pereira, A. F., \& Piuvezam, M. R., A., \&. (2020). 4-Carvomenthenol ameliorates the murine combined allergic rhinitis and asthma syndrome by inhibiting IL-13 and mucus production via p38MAPK/NF-KB signaling pathway axis. International Immunopharmacology, 88, 106938.

https://doi.org/10.1016/j.intimp.2020.106938

47. a-pyrone polyketide from Penicillium griseofulvum and their immunosuppression activity.Phytochemistry, 186, 112708. https://doi.org/10.1016/j.phytochem.2021.112708 
48. Yang, Y. H., Yang, D. S., Li, G. H., Pu, X. J., Mo, M. H., \& Zhao, P. J. (2019). Antibacterial diketopiperazines from an endophytic fungus Bionectria sp. Y1085. Journal of Antibiotics, 72(10), 752-758. https://doi.org/10.1038/s41429-019-0209-5

49. Anisha, C., Sachidanandan, P., \& Radhakrishnan, E. K. (2018). Endophytic Paraconiothyrium sp. from Zingiber officinale Rosc. Displays Broad-Spectrum Antimicrobial Activity by Production of Danthron. Current Microbiology, 75(3), 343-352. https://doi.org/10.1007/s00284-017-1387-7

50. Lü, J. M., Lin, P. H., Yao, Q., \& Chen, C. (2010). Chemical and molecular mechanisms of antioxidants: Experimental approaches and model systems. Journal of Cellular and Molecular Medicine, 14(4), 840-860. https://doi.org/10.1111/j.1582-4934.2009.00897.x

51. Sznarkowska, A., Kostecka, A., Meller, K., \& Bielawski, K. P. (2017). Inhibition of cancer antioxidant defense by natural compounds. Oncotarget. Impact Journals LLC. https://doi.org/10.18632/oncotarget.13723

52. Pham-Huy, L. A., He, H., \& Pham-Huy, C. (2008, June). Free radicals, antioxidants in disease and health. International Journal of Biomedical Science. Master Publishing Group. Retrieved from www.ijbs.org

53. Chandra, P., Sharma, R. K., \& Arora, D. S. (2020, March 1). Antioxidant compounds from microbial sources: A review. Food Research International. Elsevier Ltd.

https://doi.org/10.1016/j.foodres.2019.108849

54. Paraconiothyrium sp. P83F4/1: Antioxidant and Antiproliferative Activities an Endophytic Fungus Associated with Rheedia brasiliensis Plant. International Journal of Biotechnology for Wellness Industries (Vol. 1).

55. Saravanakumar, K., Sriram, B., Sathiyaseelan, A., Hu, X., Mariadoss, A. V. A., MubarakAli, D., \& Wang, M. H. (2021). Molecular identification, volatile metabolites profiling, and bioactivities of an indigenous endophytic fungus (Diaporthe sp.). Process Biochemistry, 102, 72-81. https://doi.org/10.1016/j.procbio.2020.12.002

56. Riss, T. L., Moravec, R. A., Niles, A. L., Duellman, S., Benink, H. A., Worzella, T. J., \& Minor, L. (2004). Cell Viability Assays. Assay Guidance Manual. Eli Lilly \& Company and the National Center for Advancing Translational Sciences. Retrieved from http://www.ncbi.nlm.nih.gov/pubmed/23805433

57. Minarni, Artika, I. M., Julistiono, H., Bermawie, N., Riyanti, E. I., \& Hasan, A. E. Z., Hasim, \&. (2017). Anticancer activity test of ethyl acetate extract of endophytic fungi isolated from soursop leaf (Annona muricata L.). Asian Pacific Journal of Tropical Medicine, 10(6), 566-571. https://doi.org/10.1016/j.apjtm.2017.06.004

58. Saha, S. K., \& Pathak, N. N. (2021). Digestion, Absorption and Metabolism of Nutrients. In Fundamentals of Animal Nutrition (pp. 219-246). Springer Singapore. https://doi.org/10.1007/978981-15-9125-9_14

59. Fair, R. J., \& Tor, Y. (2014). Antibiotics and bacterial resistance in the 21 st century. Perspectives in Medicinal Chemistry, 6(6), 25-64. https://doi.org/10.4137/PMC.S14459 
60. Singh, K., Mishra, A., Sharma, D., \& Singh, K. (2019). Antiviral and Antimicrobial Potentiality of Nano Drugs. In Applications of Targeted Nano Drugs and Delivery Systems (pp. 343-356). Elsevier. https://doi.org/10.1016/b978-0-12-814029-1.00013-2

61. Bioorganic and Medicinal Chemistry Letters, 26(16), 3950-3954. https://doi.org/10.1016/j.bmcl.2016.07.006

\section{Tables}

Due to technical limitations, tables are only available as a download in the Supplemental Files section.

\section{Figures}
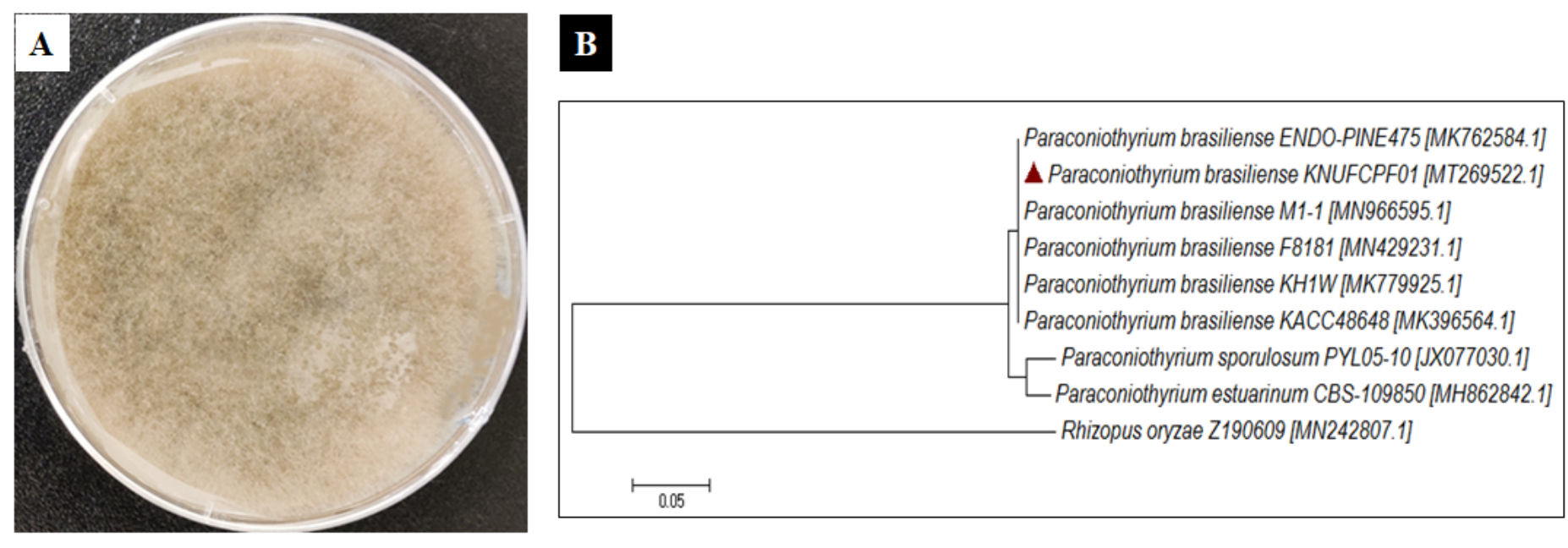

\section{Figure 1}

The culture morphology of P. brasiliense on PDA medium - A, and phylogenetic tree constructed using neighbour-joining method - B. $\Delta$ represent the isolated sequence from Capsicum annuum. 


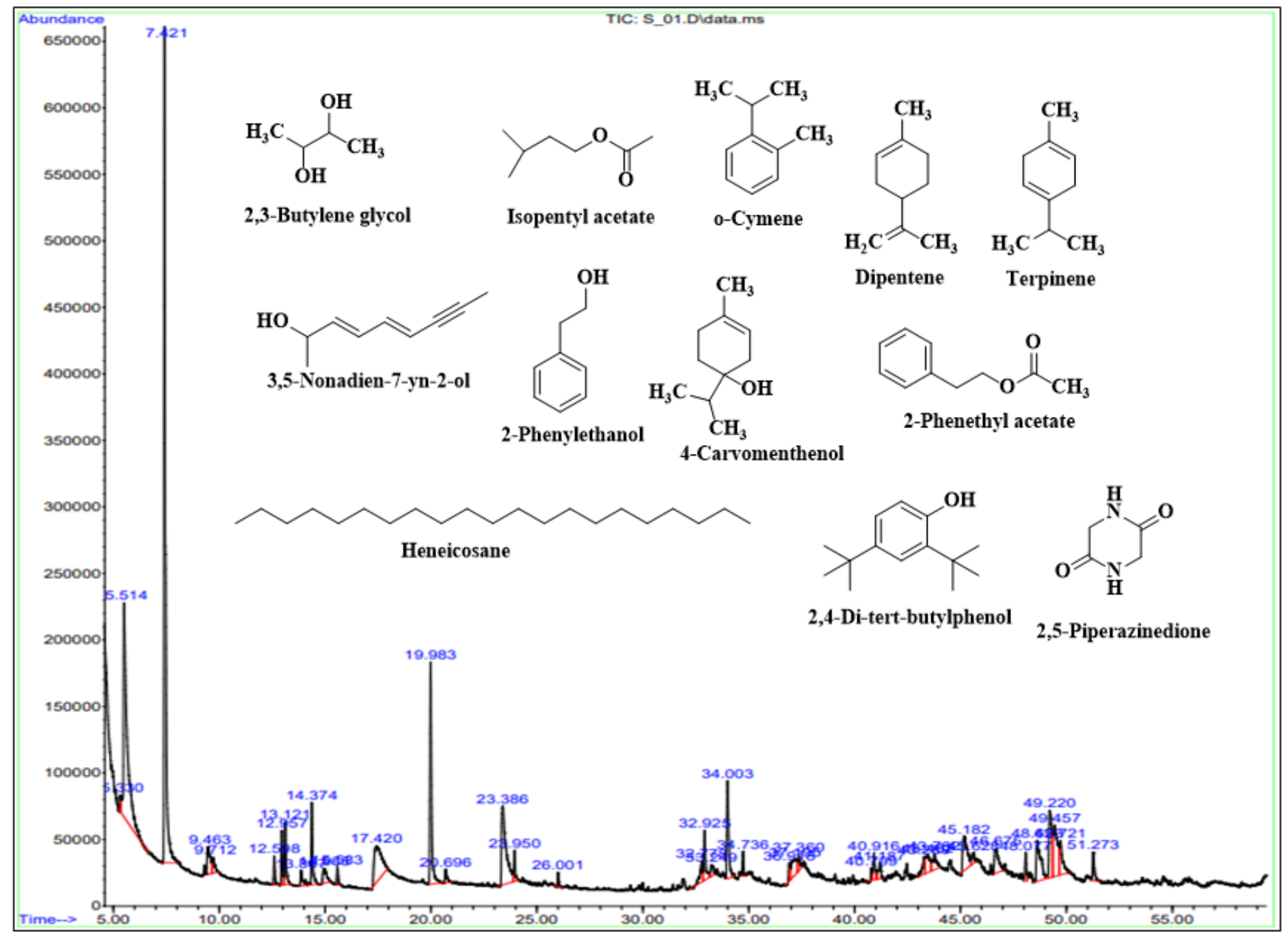

Figure 2

GC-MS spectrum of EAE of P. brasiliense. The inner image showed the existence volatile molecules in the EAE-PB. 

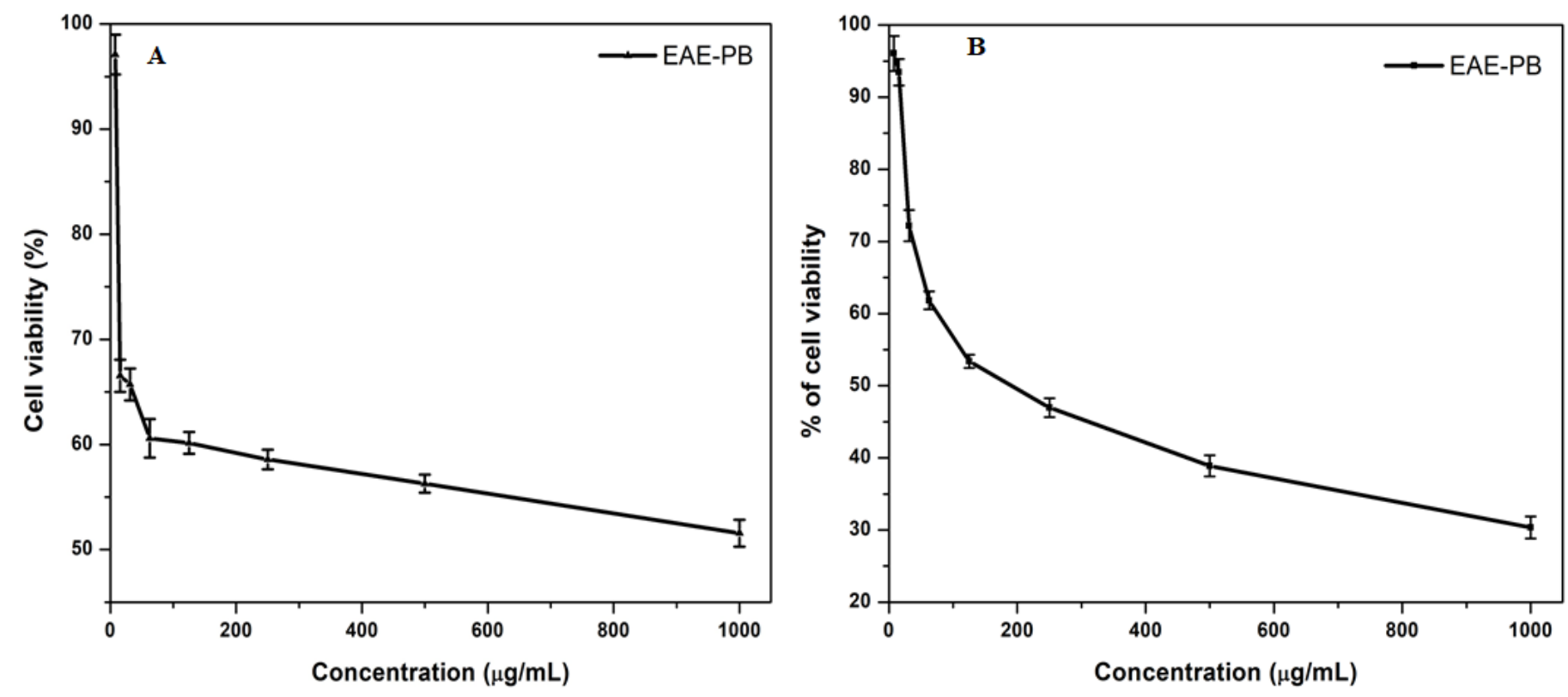

Figure 3

Cell viability of ethyl acetate extract of P. brasiliense treatment. HEK 293 cells - A; PC3 cells - B.

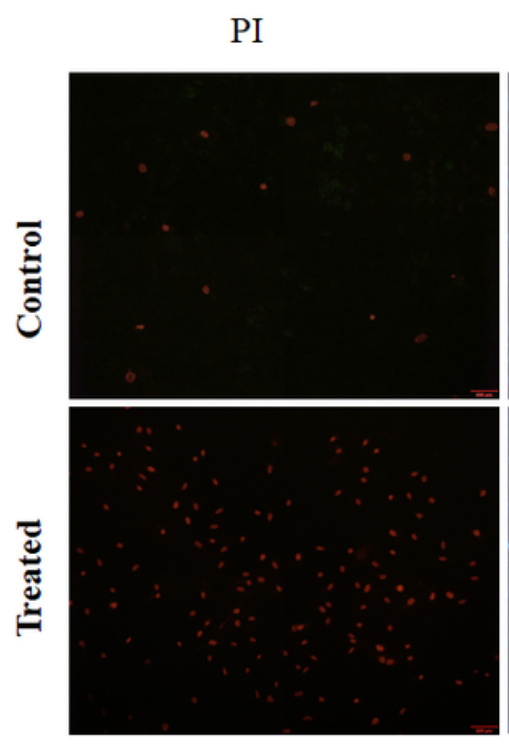

DAPI
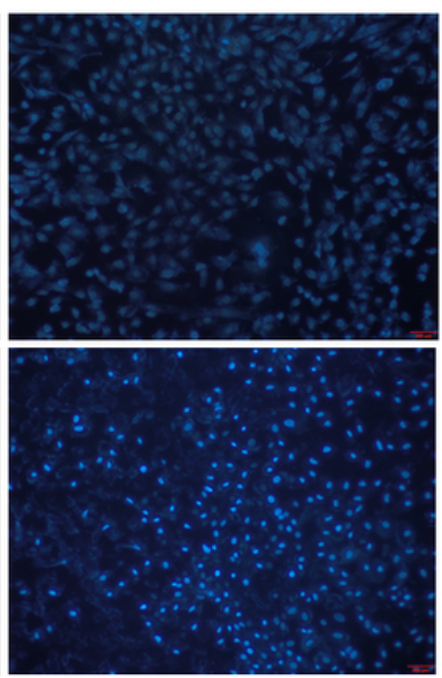

Rh123
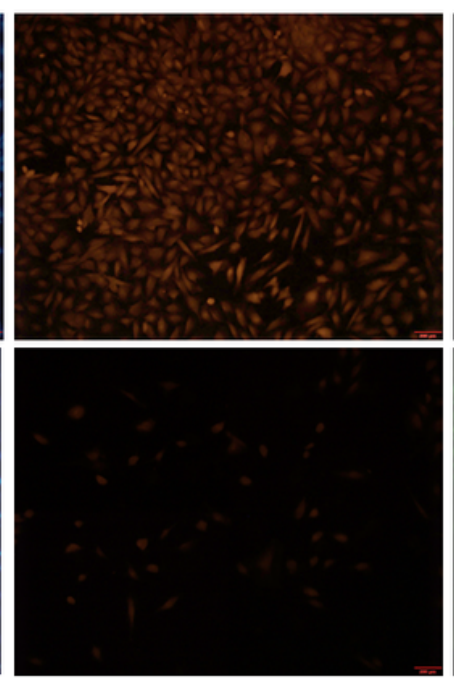

DCFH-DA

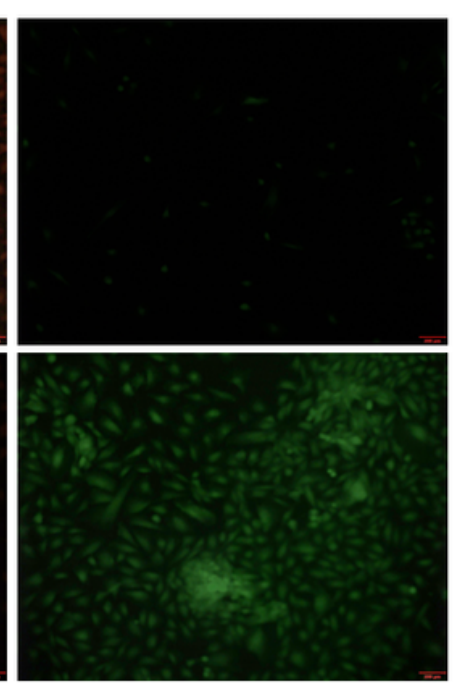

\section{Figure 4}

Apoptotic cell analysis. The IC50 concentration of EF-EA extract treated PC3 cells. Stained with propidium iodide (PI), 4',6-diamidino-2-phenylindole (DAPI), rhodamine 123 (RH-123), and 2',7'-Dichlorofluorescin diacetate (DCFH-DA). 


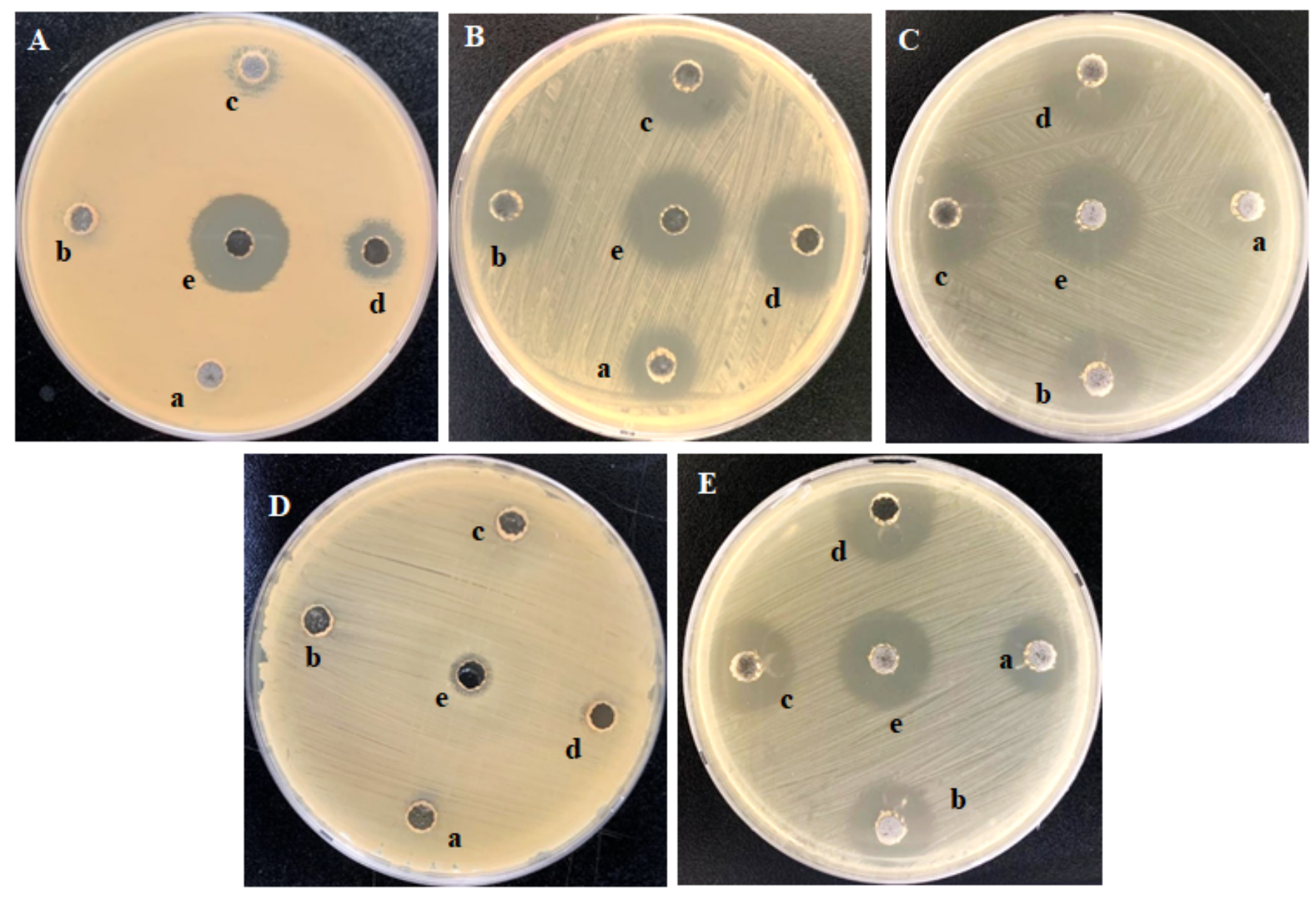

Figure 5

Antibacterial activity of ethyl acetate extract of P. brasiliense. A - Bacillus cereus; B - Staphylococcus aureus; C - Listeria monocytogenes; D - Escherichia coli, E- Salmonella enterica. a - $125(\mu \mathrm{g} / \mathrm{mL})$, b $250(\mu \mathrm{g} / \mathrm{mL}), \mathrm{c}-500(\mu \mathrm{g} / \mathrm{mL}), \mathrm{d}-1000(\mu \mathrm{g} / \mathrm{mL})$, e $-\mathrm{TCH}-20(\mu \mathrm{g} / \mathrm{mL})$. 
A

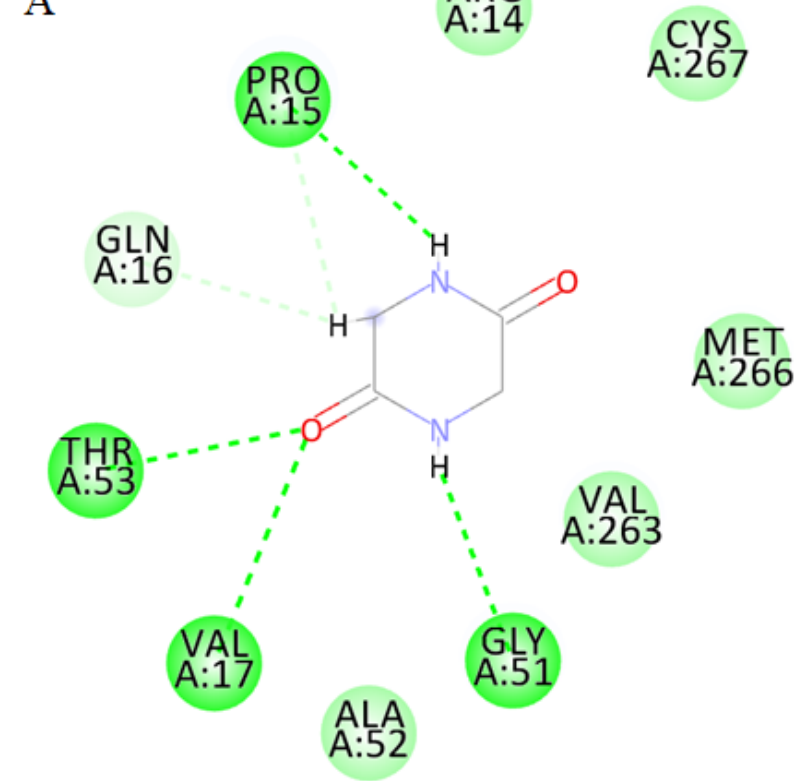

B $\quad$ SER

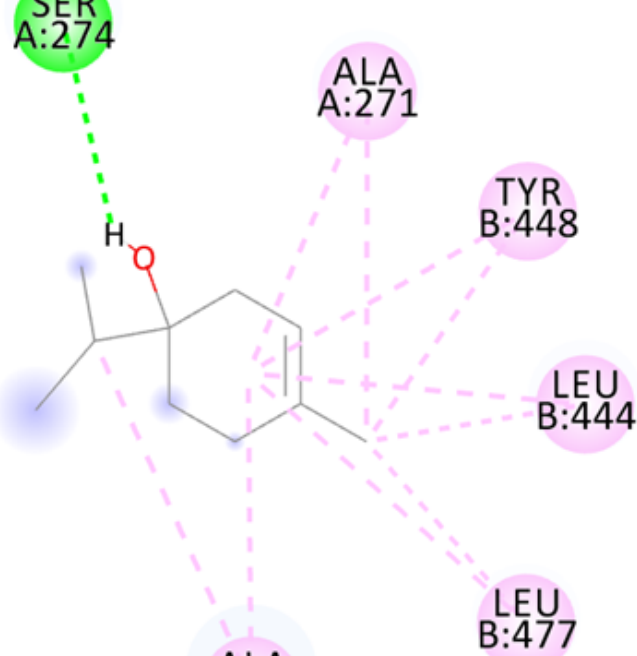

$\underset{\text { ALA }}{\text { AL: }} \cdot 445$

Interactions

Conventional Hydrogen Bond Allkyl

Interactions
$\square$ van der Woals

$\square$ Carbon Hydrogen Bond

\section{Figure 6}

2D View from a molecular modeling study of the minimum-energy structure of the complex of piperazinedione (A) and 4-carvomenthol (B) redocked in DHPS (PDB ID: 5JQ9).

\section{Supplementary Files}

This is a list of supplementary files associated with this preprint. Click to download.

- Tables.pptx 